\title{
Environmental pollution in Vietnam's craft villages
}

\author{
Thi Loi Nguyen ${ }^{1, *}$ \\ ${ }^{1}$ National Economics University; 207 Giai Phong Street, Hai Ba Trung District, Hanoi, 10000, \\ Vietnam
}

\begin{abstract}
The environment and environmental protection in Vietnam in general and in craft villages in particular are an issue that get concerned by the Party, the Government and the entire population in society. The development of craft villages has contributed significantly to socioeconomic development, helping to raise incomes and improve the lives of local people. However, the environmental pollution in craft villages is at an alarming rate. According to the verification report of the National Assembly's Committee on Science, Technology and Environment, only $26.7 \%$ of craft villages currently collect industrial wastewater and $20.9 \%$ of craft villages collect industrial solid waste. This is a big problem in dealing with environmental pollution in rural areas, especially in traditional craft villages. In this article, the author focuses on issues such as: Actual situation of environmental pollution in craft villages; causes of pollution and proposals of measures to reduce pollution and help sustainable development of craft villages.
\end{abstract}

\section{Introduction}

Developing craft villages is a proper policy of our Party and Government. Because craft villages are the place to attract local labor force, create jobs for laborers in society, contribute to improving the lives of people. However, the disadvantage/bad side of the development is that most of Vietnam's craft villages were and are now being polluted in three forms: water pollution; waste pollution and air (emissions) pollution. Meanwhile, the majority of craft villages are in small production forms, lacking the support in capital, technology and market information. Currently, most of the waste water generated from production process in craft villages is discharged directly into the environment with very high levels of pollution without any treatment. The report of the Ministry of Natural Resources and Environment shows that the concentration of pollutants according to the indices such as COD, BOD5 or the total coliform count in craft villages' wastewater exceeds the permitted standard dozens of times, especially in some places, it exceeds up to thousands of times. In addition, most of the craft villages have dust concentrations exceeding the permitted standards, the concentration of $\mathrm{SO} 2$ in rattan and bamboo handicraft villages and the processing of agricultural and food products is many times higher. The higher turnover the craft villages have, the greater the pollution and the more

\footnotetext{
*Corresponding author: nguyenthiloi1957@gmail.com
} 
difficult to control them. In order to solve the environmental pollution problems in Vietnam's craft villages, localities need to build a complete development plan for craft villages with scale, time, development conditions, and take specific steps, have proper policies and regulations for local artisans to encourage them to participate in vocational training for young generations, to provide human resources of high-quality for craft villages. At the same time, the localities should plan the production space associated with environmental protection. This is an urgent issue that authorities and the whole society must pay attention to.

\section{Document sources and research methods}

The author uses a combination of research methods, such as: survey, statistics, analysis, comparison, interpretation, inductive method .... with the sources cited in reports of the Ministry of Natural Resources and Environment; reports of localities having craft villages; articles by a number of domestic and foreign authors related to environmental protection; environmental curriculum of the National Economics University; relevant web sites.

\section{Research results}

\subsection{Actual situation of environmental pollution in Vietnam's craft villages}

Craft villages in Vietnam have existed and developed for a long time and people close-knit with traditional jobs, expand and develop craft villages. It can be said that this is one of the effective rural economic development solutions. Craft work in villages has solved the problem of redundant labor and created jobs during leisure time. According to statistics, there are $27 \%$ of households working as farmers cum other industries and $13 \%$ of households specializing in craft. Craft villages have attracted up to 11 million regular workers. In addition, income from craft village activities is a significant source of income for farming households. For example, the pottery village in Bat Trang produces thousands of fine art ceramic products for export every year. Particularly in 2009, craft villages in our country exported products reaching 900 million USD, accounting for $15 \%$ of the total production value of rural areas. Besides the encouraging signs in the development of traditional handicrafts in rural areas of Vietnam, there is an equally worry and concern that is the risk of environmental pollution from craft villages. Currently, the waste generated from many craft villages is causing serious environmental pollution. Craft villages in our country have existed and developed for a long time, these are mainly craft villages. In Vietnam, craft villages are very diverse. According to JICA statistics, in collaboration with the Ministry of Agriculture and Rural Development, there are currently 1450 craft villages nationwide distributed in 58 provinces and cities throughout the country, especially in Red River Delta there are about 800 villages. Provinces with a large number of craft villages include Ha Tay with 280 villages, Thai Binh with 187 villages, Bac Ninh with 59 villages, Hai Duong with 65 villages, Nam Dinh with 90 villages, Thanh Hoa with 127 villages... Handicraft types are also diverse and plentiful, but mainly in rattan, bamboo, weaving, embroidery, furniture production, lacquer, painting, statue etc. Works are mainly developed in craft villages as follows: Table I. Distribution of craft village types in rural areas of Vietnam Source: KC 08-09 Project. The products of these traditional craft villages have gained a foothold in the market such as Bat Trang pottery, Yen Hoa paper, Trieu Khuc weaving, Dong Ky wood mosaic (Bac Ninh), rattan, bamboo and sedge mat (Hung Yen, Thai Binh) ... These products meet the high tastes of consumers, especially foreign customers. Many handicraft products from craft villages have been competed at 
international exhibitions and also achieved high rankings such as: European Prize for fine art wooden products in Phu Khe, Gold Medal for Dong Thanh pottery. This encourages artisans, directly impacts on local people's health and becomes increasingly hot issues. This risk arises mainly from the characteristics of craft village activities, such as small-scale production, outdated and asynchronous technology, spontaneous development, mainly developed according to market demand. Another worrying fact is due to the people's ignorance about the harmful effects of production activities to the health of themselves and those around them. It is alarming that the level of environmental pollution in craft villages not only does not decrease, but also tends to increase over time. Depending on the nature of each type of craft village, the type of environmental pollution also varies. For example, in the craft villages producing rattan, bamboo ... it occurs air pollution, due to the use of sulfur when drying materials; for the industrial villages, the waste is mainly smoke, dust and toxic gases; In plastic recycling villages, when cleaning materials by washing, people have discharged into the rivers and lakes a large amount of dangerous waste such as pesticides, chemicals ... causing pollution for the water source, not only that but also when burning to melt materials, it creates an unpleasant smell... As of 2009, the number of Vietnam's craft villages distributed throughout the country with various traditional occupations are listed in the table below.

Table 1. Types of craft villages in rural areas of Vietnam ( Source: Data from KC 08-09 project).

\begin{tabular}{|c|c|c|c|c|c|c|c|}
\hline Regions & Total & $\begin{array}{c}\text { Silk, } \\
\text { leather } \\
\text { goods }\end{array}$ & $\begin{array}{c}\text { Processing } \\
\text { agricul- } \\
\text { tural } \\
\text { products } \\
\text { and } \\
\text { foodstuffs }\end{array}$ & $\begin{array}{c}\text { Recycle } \\
\text { of scrap }\end{array}$ & $\begin{array}{c}\text { Handi- } \\
\text { crafts }\end{array}$ & $\begin{array}{c}\text { Construc- } \\
\text { tion } \\
\text { materials, } \\
\text { ceramics, } \\
\text { porcelain }\end{array}$ & Others \\
\hline $\begin{array}{c}\text { Northern } \\
\text { region }\end{array}$ & 976 & 138 & 134 & 61 & 404 & 17 & 222 \\
\hline $\begin{array}{c}\text { Central } \\
\text { region }\end{array}$ & 297 & 24 & 42 & 24 & 121 & 9 & 77 \\
\hline $\begin{array}{c}\text { Southern } \\
\text { Region }\end{array}$ & 177 & 11 & 21 & 5 & 93 & 5 & 42 \\
\hline Total & 1.450 & 173 & 197 & 90 & 618 & 31 & 341 \\
\hline
\end{tabular}

Thus, production activities in Vietnam's craft villages have been seriously affecting the living environment, increasing pollution, especially wastewater pollution. This is a great challenge in developing craft villages towards sustainability, in association with environmental protection. Also according to the 2009 National Environment Report of the Ministry of Natural Resources and Environment, the survey results in 52 craft villages showed that $46 \%$ of craft villages were seriously polluted, $27 \%$ were in medium pollution and $27 \%$ mild pollution. Currently, the environmental quality in most craft villages does not meet the standards, causing laborers to be exposed to health harmful risks, including $95 \%$ from dust, $85.9 \%$ from heat and $59.6 \%$ from chemicals. Water pollution in craft villages in rural areas of Vietnam is caused by toxic inorganic compounds such as acids, bases, salts, heavy metals ... often found in mechanical, plating, casting, dyeing and bleaching craft villages. These are extremely dangerous sources of pollution, especially the characteristics of waste water from textile dyeing, which are classified as the most dangerous wastewater of all waste water types, not only affecting surface water sources, but also affecting underground water resources, causing serious illnesses to people in the adjacent areas. Besides, the coloured pigments, fibers ... often seen in the weaving, dyeing, lacquer, silk reeling villages ... have made the water change color, increase the content of organic matter in the water, causing unpleasant odors, reducing amount of oxygen dissolved in water, affecting the living environment of aquatic plants and animals, polluting the domestic water 
sources of the people. Specifically, cottage industry production villages such as Da Hoi iron and steel recycling village, Dong Ky wooden product, Phu Lam paper, etc., have contributed a large amount of untreated wastewater directly discharged into the local water system. Ngu Huyen Khe River, when flowing through these craft villages, has received sewage containing many chemicals such as acid, caustic soda, bleach, alum, coloring pigments ... from the craft villages so it is seriously polluted, becoming a sewage channel of the craft village system There are 70 households engaged in the craft village of making vermicelli and traditional cakes and services in Chua hamlet (Phu Nham commune, Phu Ninh district, Phu Tho). The number of households participating in the production is not many, but due to the outdated production process, wastewater with the large starch content is not thoroughly treated, causing the surrounding environment being seriously affected. A small number of households handle by themselves by building biogas tanks, settling tanks, but most of remaining households discharge directly into canals or rivers, so there is a lot of risk of pollution caused by waste water and waste from craft villages. In Hai Duong province, the Phu Loc wine making village, all the wastewater of nearly 200 households making wine, rice noodle and livestock waste are discharged directly into the pond, then flowed into an irrigation canal that runs through the village without any treating step. In Tong Buong village - producing rice noodle, for many years, all waste water after producing which is not treated shall be discharged directly to the village's common drainage system. Through surface water analysis of Hai Duong Center for Environmental Monitoring \& Analysis, the data indicate that the COD content exceeds from 12-15 times, TSS exceeds 2-3 times, coliform exceeds 11-19 times, ammonium exceeds from 12 - 16 times, phosphate exceeds from 26 to 31 times of the permitted standard. Also according to C36, through surveys and results of inspections by authorities, it shows that most of the craft villages are not interested in environmental protection and violating the law on environmental protection, this situation is commonplace. In Chau Khe ward (Tu Son town, Bac Ninh), among 123 production and business establishments of this metal recycling village being inspected, all of these establishments have not invested in building a treatment system of exhaust gas and wastewater. Solid waste generated during production and business activities must not be collected and transported to designated areas for treatment but arbitrarily dumped around industrial cluster areas. The analysis of the authorities on the specific pollution indicators shows that here the SO2 content is 48-60 times higher than the permitted standard, the dust content is 113-230 times higher than the permitted standard, the content of $\mathrm{NO} 2$ has exceeded the standard 50-76 times ... In the industrial cluster of Phong Khe paper craft village, Bac Ninh City, through inspection of 157/209 manufacturing facilities of the paper recycling village, the data show that most of them do not have the treatment system for waste water, exhaust gas, wastewater source is discharged into the common sewage channel of the craft village then flows to Ngu Huyen Khe river, causing serious pollution of surface water. Most facilities have not made environmental impact assessment reports or environmental protection commitments.

In 2018, at the opening speech of the Conference, Deputy Chairman of the National Assembly Office - Mr. Do Manh Hung stated that air pollution is a severe problem for the urban environment, industrial parks and craft villages in our country currently. The World Health Organization (WTO) constantly issues warnings that Vietnam is a country with a particularly high level of air pollution compared to other countries in Asia and the Pacific. In Vietnam, more than $50 \%$ of the days in the year are of poor air quality. In which, Hanoi is one of the cities with the highest level of pollution in the world. According to statistics in our country, although the total forest area has increased, reaching $40 \%$ of forest cover level, the forest quality continues to decline. For urban areas, the density of greenery does not meet the standard of coverage level. Specifically, in Hanoi and Ho Chi Minh City, this area has just reached $<4 \mathrm{~m} 2$ /person, lower than the requirements of the standard $(10-15 \mathrm{~m} 2 /$ 
person) and does not meet the role of "green lung" to help minimize air pollution. Air pollution is not only a hot issue concentrating in developed urban areas, industrial clusters but also become a concern of the whole society, considered as one of the leading agents having the risk of affecting public health. Air pollution has a negative impact on human health, especially causing respiratory diseases, affecting ecosystems and climate change (greenhouse effect, acid rain and ozone depletion)... The stronger the industrialization, the more the urbanization develops, the more the air pollution sources, the greater the pressure to change the air quality, the more important the requirements for environmental protection. Around the world, many countries are also lying on the alert of severe air pollution such as the United States, China, India, Indonesia and Malaysia... According to WHO statistics, every year around 2 million children worldwide die from acute respiratory infections, of which $60 \%$ are related to air pollution. In particular, the waste water pollution of the group of food product and agricultural product processing villages is very worrying, including cassava starch processing village in Minh Khai commune (Hoai Duc district), starch processing village in Cong Hoa, agricultural product processing village in Cat Que, vermicelli making village in Ky Thuy, spring roll sheet making village in Ngu Cau hamlet...

In 2019, according to the verification report of the National Assembly's Committee on Science, Technology and Environment, currently, only $26.7 \%$ of craft villages have collected industrial waste water and $20.9 \%$ of craft villages have collected industrial solid waste. This is a big problem in dealing with environmental pollution in rural areas, especially traditional craft villages. Also according to statistics, the country has over 5,400 craft villages, of which over $1,800 \mathrm{craft}$ villages and traditional villages are recognized. Up to $60 \%$ of craft villages are concentrated in the Northern region such as Hanoi, Bac Ninh, Hung Yen, Thai Binh, Nam Dinh ... The Central region accounts for about 23.6\%, focusing mainly in provinces such as Quang Nam, Thua Thien Hue and the Southern region account for about $16.6 \%$, concentrated mainly in Ho Chi Minh City, Can Tho, Dong Nai and Binh Duong provinces.

However, a difficult problem is that up to $46 \%$ of craft villages are severely polluted. Currently, most of the waste water produced in craft villages is discharged directly into the environment with very high levels of pollution without any treatment. The report of the Ministry of Natural Resources and Environment shows that the concentration of pollutants according to the indices such as COD, BOD5 or the total coliform count in craft villages' wastewater exceeds the permitted standard dozens of times, especially in some places, it exceeds up to thousands of times. . In addition, most of the craft villages have dust concentrations exceeding the permitted standards, the concentration of SO2 in rattan and bamboo handicraft villages and the processing of agricultural and food products is many times higher. As a commune with a developed garment industry, Tam Hiep commune (Phuc Tho district) generates about 4-5 tons of ordinary industrial waste (mainly rags) every day. According to the results of a survey in 2018-2019 of the Department of Natural Resources and Environment of Hanoi in 192 craft villages, there are 77 craft villages with severe water pollution, 36 craft villages with polution. In particular, the waste water pollution of the group of food product and agricultural product processing villages is very worrying, including cassava starch processing village in Minh Khai commune (Hoai Duc district), starch processing village in Cong Hoa, agricultural product processing village in Cat Que, vermicelli making village in Ky Thuy, spring roll sheet making village in Ngu Cau hamlet ... Waste water contains much starch, organic acids, fibers, sediments ... with high organic matter content and total high solid content and it is acidic, if not treated but discharged directly into the environment.

Hanoi is currently the locality with the largest number of craft villages in the country with 1,350 craft villages and unevenly distributed. Hoai Duc district has a record number of 
craft villages, of 53 villages there are 51 craft villages, with more than 8,300 enterprises and households of production and business, of which 12 villages are recognized as traditional craft villages. However, at the top of the list of village causing pollution in Hanoi, we must mention the agricultural and food product processing village in Duong Lieu, Minh Khai and Cat Que communes of Hoai Duc district. In these agricultural and food product processing villages, the amount of waste water produced in some places is estimated at up to $7.000 \mathrm{~m} 3 /$ day/village.

According to the plan, by 2020 , carry out the environmental treatment in 50 key craft villages, implement the Project "Protecting the environment of craft villages in Hanoi City until 2020 and orientations to 2030", Hanoi Department of Natural Resources and Environment has surveyed, sampled and conducted environmental analysis in $65 \mathrm{craft}$ villages. The results show that $60 / 65$ villages are polluted. Most of the craft villages do not have satisfactory infrastructure systems, especially inadequate wastewater supply and drainage systems. The majority of wastewater from craft villages are untreated and discharged into ponds and lakes with very high levels of pollution. Facing the above situation, over the past time, the Hanoi People's Committee has directed Department of Natural Resources and Environment to continue to perform the task of "Reviewing, evaluating and classifying craft villages". Accordingly, in 2019, reviewing and evaluating and classifying 128 craft villages. In 2020, reviewing and evaluating and classifying 107 craft villages; Develop and implement a communication plan to raise community awareness in craft villages in the period of $2018-2020$, with the goal is that $100 \%$ of craft villages will be reviewed, evaluated and classified according to Circular no. 31/2016/TT-BTNMT by MONRE to have a pollution treatment plan suitable for each type of production, with local practical conditions... The Hanoi Department of Industry and Trade offers a plan to deal with environmental pollution in craft villages of the city with an amount of VND 1,350 billion. Of which, by the end of 2020, about VND 750 billion will be allocated to build environmental treatment systems in 50 key craft villages ... In the period of 2020-2030, VND 600 billion will be needed to build an environmental treatment system at 30 other villages. In fact, pollution treatment is not effective despite large investment. The project of constructing a wastewater treatment plant in Son Dong commune has a total investment of VND 231.5 billion, implemented investment in the period of $2014-2016$, but is still at the construction stage; Cau Nga centralized wastewater treatment plant in Duong Lieu commune, with a designed capacity of $20,000 \mathrm{~m} 3$ / day and night was put into operation in October 2016 to treat craft village wastewater of 3 communes: Duong Lieu, Minh Khai and Cat Que. Since the Cau Nga wastewater treatment plant (Duong Lieu commune, Hoai Duc district, Hanoi city) has put into operation, the wastewater of 10 villages with more than 2,500 households in Mien Lang (an area inside the dyke of Day river) has been collected and treated.

\subsection{Causes of environmental pollution to craft villages}

- Because production facilities and households only pay attention to increasing sales and items without paying attention to environmental protection. In the production area as well as the drains in the agricultural and food product processing villages in Quoc Oai district, Hoai Duc district,..., there are a large amount of waste and an unpleasant odor, especially when the weather is hot and locally clogged when it rains.

- Due to people's awareness, many people know the danger level of pollution but still violate it, while the state management agencies have not focused on inspection and handling, even lack of responsibility for this work.

- Funds for investment in remediation of craft village environment pollution are limited, most of production facilities, households do not have investment capital for wastewater 
treatment systems, exhaust gas, collection and classification of solid waste ... Besides, the equipment and production technology in the craft villages are still backward, the space is cramped...

- Because the small scale of production in craft villages: enterprises operating in the field of manufacturing and processing traditional handicraft products in rural areas are mainly on household scale; More than $70 \%$ of craft villages are located in residential areas, causing pollution of wastewater in craft villages to continue to increase. Rural infrastructure such as roads, sewers, drainage channel does not meet the needs of production development ... leading to many seriously polluted craft villages, directly affecting aquatic life as well as the living environment of community, that the villagers firstly have to suffer such consequences. On the other hand, production technology and equipment are mostly outdated and at patchy level, not yet fully invested and most of production facilities in the craft villages are focusing only on production and business, they do not pay adequate attention to the collection and treatment of waste, toxic dust, waste water from craft villages.

- Legal documents on environmental protection for craft village are inadequate; no financial support policies to encourage relocation of production establishments to concentrated production sites, causing difficulties in synchronous handling of environmental pollution. Programs, projects and tasks on environmental protection often require large capital sources, making it difficult to ensure progress due to the need to balance resources, especially the programs, tasks, and the project using a budget state source

\subsection{Solutions to reduce environmental pollution in Vietnam's craft villages}

Solving environment issues in craft village requires a combination of levels, sectors and people in the such villages. Besides, there should be regulations on environmental protection in craft villages, which clearly states the obligations of each branch, sector and local authorities in management. The solutions needed to be implemented are:

- Completing the system of legal documents on environmental protection in craft villages such as environmental impact assessment and environmental protection commitment for craft villages; Integrating the content of craft village environmental protection into the state's target standards on new rural construction and making local development strategies, plannings.

- Completing the environmental management system at ward, commune and town levels and considering this to be an effective environmental management system in craft villages to maintain and develop traditional occupations in the period of industrialization, modernization, craft villages have established craft village associations to gather and attract the craft village people to join hands to build and develop the village. Therefore, it is very important that the natural resources and environment sector and the City People's Committee need to tighten management and timely prevent urgent environmental problems in the coming time.

- Strengthening the environmental protection in industrial parks and industrial clusters, especially focusing on remedying pollution, improving the environment of rural areas and craft villages currently.

- Re-planning with specific solutions for each type of craft village; applying technical technology into production; building wastewater and waste treatment systems that meet environmental protection standards.

- Continueing to develop and complete policies and legal systems to create a legal framework for environmental protection. Strengthening the inspection and supervision to help sustainable development of craft villages as well as a basis for prioritizing green 
development, linking economic development goals with environmental protection.

- Localities nationwide should continue to implement environmental pollution treatment in craft villages with high pollution density; urgently introduce craft villages causing serious environmental pollution into planned industrial clusters of craft villages, contributing to improving the environment, improving the health of people in craft villages.

- Continueing to improve the legal system on environmental protection, in which sanctions must be really strong enough to deter those violating.

- It is necessary to build an integrated system of environmental management in factories and industrial parks according to international standards, and at the same time organize close supervision towards a better and more friendly environment for people.

- Strengthening the work of grasping the situation, inspection and supervision of the environment; closely coordinate between specialized agencies, especially between environmental inspection forces and environmental police forces at all levels, in order to detect, prevent, and handle in time and thoroughly environment-polluting acts of organizations and individuals.

- Improving the professional capacity of a team in charge of environmental works; equipping with modern technical facilities to effectively serve the operation of these forces.

- Focusing on the planning of the development of industrial zones, clusters, spots, craft villages and urban centers, ensuring high science, on the basis of careful and comprehensive calculation of development trends, from that having the right policy; avoid rampant and asynchronous planning.

- In 2020, carry out the environmental treatment in 50 key craft villages, implement the Project "Protecting the environment of craft villages in Hanoi City until 2020 and orientations to 2030". Department of Natural Resources and Environment continues to perform the task of "Reviewing, evaluating and classifying craft villages". Accordingly, in 2019, reviewing and evaluating and classifying 128 craft villages. In 2020, reviewing and evaluating and classifying 107 craft villages; Develop and implement a communication plan to raise community awareness in craft villages in the period of 2018-2020, with the goal is that $100 \%$ of craft villages will be reviewed, evaluated and classified according to Circular no. 31/2016/TT-BTNMT by MONRE to have a pollution treatment plan suitable for each type of production, with local practical conditions.

- The Hanoi Department of Industry and Trade offers a plan to deal with environmental pollution in craft villages of the city with an amount of VND 1,350 billion. Of which, by the end of 2020, about VND 750 billion will be allocated to build environmental treatment systems in 50 key craft villages ... In the period of 2020-2030, VND 600 billion will be needed to build an environmental treatment system at 30 other villages.

- Propagating, educating and raising awareness on the protection of water resources such as: focusing on communication on the treatment of waste water sources in craft villages on the mass media; improving the capacity of environmental communication work in the state management agencies in charge of the environment, especially for district and commune officials, closely coordinating with organizations, agencies and the mass media means in media activities.

- Encouraging the application of scientific and technological advances to minimize waste water source polluting the environment, along the direction of sustainable development; giving priority to mechanisms and finance for scientific and technological research on wastewater treatment in craft villages (green, clean and environmentally friendly technologies) in centers, research institutions, schools, factories and enterprises; actively applying environmental scientific research results on the treatment of waste water into localities' activities, promoting research and application of techniques and technologies such as transfering clean technology and wastewater treatment technology for small-scale production establishments towards simple, stable operation, cost-saving and effective 
treatment of water pollution.

- Improving "mindset of officials" to create drastic changes in the awareness of those in charge in wards and communes having craft villages. The common viewpoint is to maintain, protect and develop craft villages in a sustainable manner. Therefore, the issues of environmental violations in craft villages will firstly be let enterprises and craft villages have a reasonable time to "treat by themselves". If the "self-treatment" is not good, the environment police force will strictly handle it according to the law.

There should be a combination of levels, sectors and people in the such villages. Besides, there should be regulations on environmental protection in craft villages, which clearly states the obligations of each branch, sector and local authorities in management. At the same time, to complete the system of legal documents on environmental protection in craft villages such as environmental impact assessment and environmental protection commitment for craft villages; Integrating the content of craft village environmental protection into the state's target standards on new rural construction and making local development strategies, plannings.

- Completing the environmental management system at ward, commune and town levels and considering this to be an effective environmental management system in craft villages to maintain and develop traditional occupations in the period of industrialization, modernization, craft villages have established craft village associations to gather and attract the craft village people to join hands to build and develop the village. Therefore, it is very important that the natural resources and environment sector and the City People's Committee need to tighten management and timely prevent urgent environmental problems in the coming time. At the same time, strengthening environmental protection in industrial parks and industrial clusters, especially focusing on remedying pollution, improving the rural environment and craft villages currently.

\section{Conclusion}

Together with the overall economic development of the country, the economy created by craft villages has contributed significantly to the national income. However, along with the development of the craft village economy is the increase in pollution of the living environment of the people. In order to solve the problem of environmental pollution in Vietnam's craft villages, the State needs to build a complete development plan for craft villages with with appropriate scale, time and conditions. Performing regular inspection and supervision and taking strict measures to handle. Implementing the propagation and dissemination of environmental laws, having preferential policies on loans, invest technology for craft villages, and taking specific steps, have proper policies and regulations for local artisans to encourage them to participate in vocational training for young generations, to provide human resources of high-quality for craft villages. At the same time, the localities should plan the production space associated with environmental protection. This is an urgent issue that authorities and the whole society must pay attention to.

\section{References}

1. L.T. Can, Capacity Building in National Environmental Policy (Springer, Berlin, Heidelberg, 2002) DOI: 10.1007/978-3-662-04794-1_18

2. H.V. Nien, Vietnam Environment Administration Journal 4, 18-22 (2020)

3. H.N. Hoang, Vietnam Environment Administration Journal 6, 3-6 (2018)

4. P.T.T. Uyen, Vietnam Environment Administration Journal 3, 30-33 (2020) 
5. P.N. Dang, Environment and development in the context of climate change (National Political Publishing House, 2020)

6. N.T. Thang, D.T.P. Anh, Waste Management and Resource Efficiency (Springer, Singapore, 2019) DOI: 10.1007/978-981-10-7290-1_67

7. M.D. Nguyen, Environ Dev Sustain 13, 35-50 (2011) https://doi.org/10.1007/s10668-0109246-8

8. T.C. Hoang, M.C. Black, S.L. Knuteson et al., Environmental Management 63, $433-$ 436 (2019). DOI: 10.1007/s00267-019-01144-Z

9. J. Voeten, N. Roome, N.T. Huong, G. de Groot, J. de Haan, Responsible Innovation (Springer, Dordrecht, 2014)

10. C.D. Tran, S.P. Salhofer, J. Mater. Cycles Waste Manag. 20, 110-126 (2018) DOI: 10.1007/s10163-016-0549-1 